\title{
ISLAM DAN PENDIDIKAN MULTIKULTURALISME
}

\author{
ZAENAL MUSTOFA \\ zaynalmustofa03@gmail.com \\ UNIVERSITAS ISLAM AL IHYA KUNINGAN
}

\begin{abstract}
The education institution has the big role to influence the implementation of multiculturalism in this country. First, It is started from the university which is the highest level of education. The university institution can apply and conduct the multiculturalism education by organising and developing the concept of multicultural, e.g. the study centre of Islam for non-moslems, the colaboration between Islamic University and state university, morever non-islamic university. Second, The school instution also has the influential role in developing the multicultural education. There are two prime component, first is the teacher. The teacher hold the urgent role in implementing the multicultural value for their students. It is supposed that the teacher has the paradigma of diversity understanding, so they are able to teach their students by giving the argument democrately towards the world multicultural issues or conflicts which occured. The islam education based on the multiculticultural material can be developed and applied in some learning subjects. Finally, there will be the balance between Islam and multicultural and the conflicts can be minimized.
\end{abstract}

Keywords: Islam, Education, Multiculturalism

\begin{abstract}
Abstrak
Institusi pendidikan memiliki peran besar dalam penerapan pendidikan multikulturalisme di negeri ini. Pertama, dimulai dari universitas yang merupakan tingkat tertinggi pendidikan. Lembaga perguruan tinggi dapat menerapkan dan melaksanakan pendidikan multikulturalisme dengan menyelenggarakan dan mengembangkan konsep multikultural, misalnya pusat studi Islam untuk nonmuslim, kolaborasi antara perguruan tinggi Islam dan perguruan tinggi negeri, terutama perguruan tinggi non-Islam. Kedua, sekolah juga memiliki peran yang sangat berpengaruh dalam mengembangkan pendidikan multikultural. Ada dua komponen utama, pertama adalah guru. Guru memegang peran penting dalam menerapkan nilai multikultural bagi siswa mereka. Hal ini dapat dilakukan jika guru memiliki paradigma pemahaman keberagaman, sehingga mereka mampu untuk mengajar siswa mereka dengan memberikan argumen yang bersifat demokratis terhadap isu multikultural dunia atau mengenai konflik yang sedang terjadi . Pendidikan islam berbasis multikultural dapat dikembangkan dan diterapkan dibeberapa mata pelajaran. Pada akhirnya, akan ada keseimbangan antara Islam dan multikultural dan konflik dapat diminimalkan
\end{abstract}

Kata-kata kunci : Islam, Pendidikan, Multikulturalisme 


\section{PENGANTAR}

Salah satu masalah terbesar peradaban bangsa yang tidak kunjung usai adalah masalah ketidakharmonisan dan ketidaktentraman kehidupan berbangsa dan berkebudayaan. Kesatuan dan persatuan bangsa saat ini sedang diuji eksistensinya. Praktek kekerasan yang diatasnamakan agama, dari fundamentalis, radikalisme dan terorisme akhir-akhir ini semakin sering terjadi di tanah air. Disharmoni akan menjadi sangat runcing ketika seluruh lapisan masyarakat tidak bisa menerima perbedaan. Berbagai indikator yang memperlihatkan adanya tanda-tanda perpecahan bangsa, dengan jelas mudah kita baca.

Beberapa konflik yang terjadi seperti di Ambon, Poso, seperti api dalam sekam yang sewaktu-waktu bisa meledak walaupun berkali-kali bisa diredam. Peristiwa tersebut tidak sedikit telah merenggut korban baik jiwa dan menghancurkan ratusan tempat ibadah baik masjid maupun gereja. Peristiwa atau tragedi 11 September 2001 merupakan titik awal pemicu sehingga Islam menjadi sangat makin terkenal di antero jagad. Setiap hari, setiap jam, setiap menit bahkan setiap detik dalam kurun satu tahun lebih, seluruh media massa yang bertaraf international mereportasekan topik yang menurut mereka adalah aktual. Opini-opini tentang diskursus Islam terus berkembang.

Ini menarik perhatian banyak kalangan di berbagai belahan dunia, termasuk di Indonesia. Pertarungan wacana dan ideologi Islam kembali muncul yang diwakili oleh dua kutub yang saling berseberangan, yakni antara kubu fundamental dan kubu liberal. Tidak mengherankan jika wacana ini menimbulkan perdebatan pendapat dan konflik sosial tidak bisa dihindari. Sebagai contoh, timbulnya klaim kebenaran (truth claim), saling tuduh-menuduh, penghakiman dan bahkan pengkafiran menjadi makanan sehari-hari dalam kehidupan beragama di tanah air ini pada saat itu.

Fenomena di atas merupakan realitas empirik yang sering dijumpai beberapa tahun yang lalu. Sedangkan saat-saat ini wacana tersebut agak redup dan meredam, karena dikalahkan oleh isu-isu politik, infotainment selebriti, peristiwa bencana alam, dan yang most streaming adalah infotainment korupsi, dan berita pra pemilu pileg dan pilpres 2014. Namun, bukan berarti perdebatan Islam di tanah air menjadi pause, justru dengan ramainya wacana tersebut menjadikan perdebatan agama semakin ramai yakni ditandai dengan menculnya banyak kelompok kajian, aliran agama, dan golongan-golongan dalam semua agama, dalam hal ini khususnya islam.

Multikultur di Indonesia sangatlah kompleks sekali sehingga sangat rentan sekali menyebabkan multiconflict juga. Mulai dari budaya, etnik, bahasa, hingga agama, masingmasing berpotensi untuk berkembang membentuk golongan-golongan yang berbeda-beda dan masing-masing juga berpotensi menimbulkan konflik. Dalam Islam sendiri telah berkembang menjadi berbagai macam kultur sehingga menghasilkan multiislam. Dan parahnya kekhawatiran hiperbol oleh kaum islam akan kehadiran keperbedaan yang dianggap menghantui keutuhan dan kesucian ajaran agama islam kian lama kian meruncing.

Hal ini dibuktikan dengan salah satu kondisi umat islam yang belum siap menerima secara komprehensif tentang perbedaan termasuk perbedaan pendapat, madzhab yang merupakan suatu keniscayaan yang tidak dapat dielakkan. Padahal Islam itu sendiri bersifat dinamis, multi dimensi, dan multi tafsir.

Pertanyaan yang timbul adalah Siapakah yang akan bertanggungjawab akan permasalahan umat yang memiliki opini opini bengkok terhadap kemultikulturan baik 
Indonesia pada umumnya dan Islam pada khususnya. Bermula dari latar belakang tersebut, lembaga-lembaga disiplin ilmu tinggi baik PTN maupun PTS hendaknya sangat bertanggung jawab sekali dalam menerbitkan opini-opini pencerah yang bisa menjajah opini-opini umat islam sendiri yang masih dianggap rentan untuk menimbulkan konflik karena rupanya pemerintah sudah lesu untuk meresponnya. 


\section{PEMBAHASAN}

\section{Pengertian Multikulturalisme}

Multikulturalisme berasal dari dua kata; multi (banyak/beragam) dan cultural (budaya atau kebudayaan), yang secara etimologi berarti keberagaman budaya. Budaya yang mesti dipahami, adalah bukan budaya dalam arti sempit, melainkan mesti dipahami sebagai semua dialektika manusia terhadap kehidupannya. Dialektika ini akan melahirkan banyak wajah, seperti sejarah, pemikiran, budaya verbal, bahasa dan lain-lain (P.J Zoetmulder dalam Sariban : 2012).

Secara sederhana multikulturalisme berarti "keberagaman budaya". Sebenarnya, ada tiga istilah yang kerap digunakan secara bergantian untuk menggambarkan masyarakat yang terdiri keberagaman tersebut baik keberagaman agama, ras, bahasa, dan budaya yang berbedabeda yaitu pluralitas (plurality), keragaman (diversity), dan multikultural (multicultural) (Charles Taylor dalam Hanum : 2009).

Dari ketiga istilah itu sesungguhnya tidak merepresentasikan hal yang sama, walaupun semuanya mengacu kepada adanya 'ketidaktunggalan'. Konsep pluralitas mengandaikan adanya 'hal-hal yang lebih dari satu' (many); keragaman menunjukkan bahwa keberadaan yang 'lebih dari satu' itu berbeda-beda, heterogen, dan bahkan tak dapat disamakan. Dibandingkan dua konsep terdahulu, multikulturalisme sebenarnya relatif baru. Secara konseptual terdapat perbedaan signifikan antara pluralitas, keragaman, dan multikultural. Inti dari multikulturalisme adalah kesediaan menerima kelompok lain secara sama sebagai kesatuan, tanpa memperdulikan perbedaan budaya, etnik, jender, bahasa, ataupun agama. Apabila pluralitas sekadar merepresentasikan adanya kemajemukan (yang lebih dari satu), multikulturalisme memberikan penegasan bahwa dengan segala perbedaannya itu mereka adalah sama di dalam ruang publik. Multikulturalisme menjadi semacam respons kebijakan baru terhadap keragaman.

Dengan kata lain, adanya komunitaskomunitas yang berbeda saja tidak cukup; sebab yang terpenting adalah bahwa komunitas-komunitas itu diperlakukan sama oleh negara. Oleh karena itu, multikulturalisme sebagai sebuah gerakan menuntut pengakuan (politics of recognition)3 terhadap semua perbedaan sebagai entitas dalam masyarakat yang harus diterima, dihargai, dilindungi serta dijamin eksisitensinya.

Kosep tentang mutikulturalisme, sebagaimana konsep ilmu-ilmu sosial dan kemanusiaan yang tidak bebas nilai (value free), tidak luput dari pengayaan maupun penyesuaian ketika dikaji untuk diterapkan. Demikian pula ketika konsep ini masuk ke Indonesia, yang dikenal dengan sosok keberagamannya. Muncul konsep multikulturalisme yang dikaitkan dengan agama, yakni "multikulturalisme religius" yang menekankan tidak terpisahnya agama dari negara, tidak mentolerir adanya paham, budaya, dan orang-orang yang atheis (Sariban, 2012).

Dalam konteks ini, multukulturalisme dipandangnya sebagai pengayaan terhadap konsep kerukunan umat beragama yang dikembangkan secara nasional. Istilah multikulturalisme sebenarnya belum lama menjadi objek pembicaraan dalam berbagai kalangan, namun dengan cepat berkembang sebagai objek perdebatan yang menarik untuk dikaji dan didiskusikan. Dikatakan menarik karena memperdebatkan keragaman etnis dan budaya, serta penerimaan kaum imigran di suatu negara, pada awalnya hanya dikenal dengan istilah puralisme yang mengacu pada keragaman etnis dan budaya dalam suatu daerah atau 
negara. Baru pada sekitar pertengahan abad ke-20, mulai berkembang istilah multikulturalisme. Istilah ini, setidaknya memiliki tiga unsur, yaitu: budaya, keragaman budaya dan cara khusus untuk mengantisipasi keanekaragaman budaya tersebut. Secara umum, masyarakat modern terdiri dari berbagai kelompok manusia yang memiliki status budaya dan politik yang sama. Selanjutnya, demi kesetaraan masa kini, pengakuan adanya pluralisme kultural menjadi suatu tuntutan dari konsep keadilan sosial (Okke KS Zaimar, 2007: 6).

\section{Multikulturalisme Menurut Islam}

Multikultural pada dasarnya tidak bertentangan dengan ajaran Islam, khususnya alQur'an yang menjadi sumber hukum agama Islam. Keanekaragaman yang ada justru menjadi kekayaan intelektual untuk dikaji, sebagaimana beberapa ayat al-Qur'an yang menjelaskan hal tersebut. Dengan pendidikan multikultural diharapkan setiap individu atau kelompok bisa menerima dan menghargai setiap perbedaan, hidup berdampingan dengan damai dan tenang. Sehingga terbentuk sebuah negara dan bangsa yang damai dan sejahtera. Konsep multikultural dalam Al Qur'an dapat di lihat dalam : Al Hujurot ayat: 13 yang artinya : "Hai manusia, Sesungguhnya Kami menciptakan kamu dari seorang laki-laki dan seorang perempuan dan menjadikan kamu berbangsa - bangsa dan bersuku-suku supaya kamu saling kenal-mengenal. Sesungguhnya orang yang paling mulia diantara kamu disisi Allah ialah orang yang paling taqwa diantara kamu. Sesungguhnya Allah Maha mengetahui lagi Maha Mengenal".

Al Baqoroh :148 yang artinya: "Dan bagi tiap-tiap umat ada kiblatnya (sendiri) yang ia menghadap kepadanya. Maka berlomba-lombalah (dalam membuat) kebaikan. di mana saja kamu berada pasti Allah akan mengumpulkan kamu sekalian (pada hari kiamat). Sesungguhnya Allah Maha Kuasa atas segala sesuatu."

Dari kedua ayat tersebut di atas dapat disimpulkan bahwa Allah SWT sebenarnya dengan tegas menyatakan bahwa di muka bumi ini terdapat konsep multikultur yang terdiri dari multination (bangsa) dan multietnik. Sehingga terdapat perbedaan-perbedaan. Tetapi dengan perbedaan tersebut kita diperintahkan untuk saling mengenal (ta'aruf), menghargai, menerima keberagaman tersebut sehingga manusia tersebut memilki kompetensi-kompetensi untuk menjadikan dirinya mulia di sisi Allah SWT. Ada tiga model terbentuknya masyarakat multikultur, yang pertama karena migrasi dan membentuk negara baru, kasus Amerika dan Australia, kemudian yang kedua adalah model negara yang tadinya monokultur, karena adanya perpindahan penduduk dari negeri lain maka kemudian jadi multikultur. Contohnya Inggris. Yang ketiga adalah model negara kepulauan yang terdiri dari berbagai suku bangsa dan budaya yang berbeda menyatukan diri jadi sebuah bangsa Multikultur. Contohnya Indonesia.

Dikalangan umat Islam sendiri juga bisa dikatakan multiislam, dalam bidang Aqidah kita mengenal ada: Qodariyah, jabariyah, Mu'tazilah, Asya'ariyah, maturidiyah, ahlussunah, Syi'ah, dll. Dalam masalah Fiqh kita mengenal beberapa madzab seperti : madzab Maliki, Hambali, Hanafi, Syafi'i. Dalam bidang tasawuf ada: Qodariyah, Naqsabandiyah, Idrisiyah, Satariyah, Hakmaliyah, Al-Murobittun. Dari segi pluralitas organisasi kemasyarakatan kita mengenai berbagai ormas seperti: NU, Muhammadiyah, Persis, Mathla'ul Anwar, PUI, AlIrsyad, SI, FUUI, DDI,MUI, dll. Dari segi pluralitas politik kita mengenal partai politik: PPP, PBB, PKS, PAN, PKB, PMB,Golkar, PD, PDIP, dll. Dari segi pemahaman kita juga mengenal model pemahaman: tekstualist, substansialis, liberal, konservatif, fundamentalis, radikal, moderat.

Dari sisi negatif pluralitas masyarakat Indonesia dapat menimbulkan berbagai persoalan seperti yang sekarang dihadapi bangsa ini. Perseteruan politik, kekerasan dan 
kerusuhan massal, separatisme, serta hilangnya rasa kemanusiaan untuk selalu menghormati hak-hak orang lain, adalah bentuk nyata konsekuensi multikulturalisme itu. Realitas dan konsekuensi 'multikultural' itu agaknya kini dihadapkan pada kebutuhan mendesak untuk merekonstruksi 'kebudayaan nasional Indonesia', yang bisa menjadi 'integrating force' yang mengikat semua keragaman etnis dan budaya.

\section{Multikulturalisme di Indonesia}

Tak bisa dipungkiri, negara-bangsa Indonesia terdiri dari berbagai etnis, budaya, agama dan lainnya sehingga bisa disebut sebagai 'masyarakat multikultural'. Bahkan, dapat dikatakan, Indonesia adalah salah satu negara multikultural terbesar di dunia. Hal ini dapat dilihat dari kondisi sosio-kultural maupun geografis Indonesia yang begitu beragam dan luas. Jumlah pulaunya sekitar 13.000 buah (Ensiklopedia Nusantara). Populasi penduduknya lebih 220 juta jiwa, terdiri dari 300 suku yang menggunakan hampir 200 bahasa berbeda, menganut agama dan aliran kepercayaan yang beragam. Sebagai contoh di pulau Jawa saja ada beberapa suku dan etnis seperti suku Jawa, Sunda Madura, Betawi, China, Arab, dan Etnis lainnya. Dari segi bahasa ada bahasa: Jawa, Sunda, Madura, Cirebon, Baduy, dan beberapa bahasa Lokal, dari segi agama: Islam, Protestan, Katholik, Hindu, Budha, dan beberapa agama / kepercayaan lokal (kaharingan, pelbegu, baduy,dll).

Indonesia adalah negara yang kaya akan budaya, adatistiadat serta suku bangsa. Menurut Huntington, keanekaragaman di Indonesia ini harus di waspadai karena telah banyak kejadian-kejadian yang menyulut kepada perpecahan yang disebabkan adanya faham sempit tentang keunggulan sebuah suku tertentu. Faham sukuisme sempit inilah yang akan membawa perpecahan seperti konflik di timur-timur, di Aceh, di Ambon, entah konflik itu muncul semata-mata karena perselisihan diantara masyarakat sendiri atau ada seorang yang menjadi provokator yang jelas konflik tersebut adalah terjadi karena tidak menginginkan adanya Indonesia yang kokoh dengan keanekaragamannya.

Dari adanya konflik akibat dari pihak yang tidak suka dengan keanekaragaman maka Indonesia memunculkan adanya "Bhineka Tunggal Eka" ini adalah mengandung makna yang luar biasa baik eksplisit dan implisit. Secara eksplisit semboyan tersebut mampu mengangkat dan menunjukkan akan keanekaragaman bangsa Indonesia tetapi bangsa Indonesia yang multiculturalisme akan tetapi bersatu dalam kesatuan yang kokoh. Secara implisit "Bhineka Tunggal Eka" mampu memberikan semacam dorongan moral dan spiritual kepada bangsa Indonesia, khususnya pada massa pasca kemerdekaan untuk senantiasa bersatu dalam melawan ketidakadilan para penjajah, walaupun dari suku, agama dan bahasa yang berbeda.

Bukti adanya multikulturalisme yang ada di Indonesia adalah merupakan bukti adanya bahwa Indonesia adalah kaya akan keanekaragaman budaya, sehingga Indonesia dituntut agar supaya bagaimana Indonesia memperhatikan akan keanekaragaman agar tetap pada satu kesatuan yang kokoh dan bukti adanya tanggung jawab Indonesia terhadap multicultural adalah dengan adanya pedoman "Bhineka Tunggal Eka", kemudian munculnya Sumpah Pemuda pada tahun 1928 merupakan suatu kesadaran akan perlunya mewujudkan perbedaan ini yang sekaligus dimaksudkan untuk membina persatuan dan kesatuan dalam menghadapi penjajah Belanda. Tidak hanya dua hal tersebut, tapi lahirnya Piagam Jakarta juga merupakan bentuk penghargaan terhadap sebuah multikulturalisme dalam arti luas.

Tapi terkadang tidak bisa dipungkiri juga ketika multikulturalisme menjadi suatu masalah, memang benar bahwa konflik dalam masyarakat merupakan proses interaksi yang alamiah, karena masyarakat tidak selamanya bebas konflik, hanya saja persoalannya menjadi 
lain, jika konflik sosial yang berkembang dalam masyarakat tidak lagi menjadi sesuatu yang positif, tetapi berubah menjadi destruktif bahkan anarkis seperti kasus Ambon, Poso, Maluku, GAM Aceh dan konflik sosial berbau SARA (Agama) ini tidak dianggap remeh dan harus segera diatasi secara memadai dan proporsional agar tidak menciptakan disintegrasi sosial.

Kebanyakan konflik yang terjadi karena sebab ingin mempertahankan hidupnya dan dipacu adanya status dan kelas sosial, serta tidak jarang juga dipacu adanya perbedaan etnik, agama dan sebagainya. Faktor-Faktor Penyebab Terjadinya Konflik Multikulturalisme di Indonesia dapat menimbulkan konflik apabila antara budaya yang satu dengan yang lainnya tidak ada rasa kebersamaan dalam segala hal. Faktor penyebabnya menurut Samsul Rizal adalah sebagai berikut:

\section{Faktor Ekonomi dan Politik}

Faktor ini sangat berpotensi nomer wahid dalam pemicu terjadinya konflik sosial di berbagai daerah di Indonesia. Salah satu penyebabnya adalah ketidakpuasan kalangan masyarakat terhadap terjadinya kesenjangan sosial yang sangat tajam antara si kaya dengan si miskin, antara pejabat dengan rakyat jelata, antara majikan dengan buruh, antara Aparat dengan Sipil, antara pengusaha besar dengan pedagang kecil. Hal tersebut terjadi akibat dari kebijakan-kebijakan pemerintahdalam bidang sosial, politik dan ekonomi yang tidak memihak pada rakyat kecil.

Ketidakpuasan tersebut diwujudkan dalam bentuk protes-protes sosial yang memicu terjadinya kerusuhan sosial, didukung lagi dengan agama yang menopang untuk membolehkan aksi-aksi tersebut.

2. Faktor Agama itu sendiri

a. Pendirian rumah ibadah yang tidak didirikan atas dasar pertimbangan situasi dan kondisi ummat bergama serta peraturan erundang-undangan yang berlaku.

b. Penyiaran agama yang dilakukan secara berlebihan dan memaksakan kehendak bahwa agamanyalah yang paling benar, sedangkan agama lain adalah salah. Lebih berbahaya lagi manaka peniaran agama itu sasaran utamanya adalah penganut agama tertentu.

c. Penodaan Agama dalam bentuk pelecehan atau menodai doktrin da keyakinan suatu agama tertentu baik dilakukan oleh perorangan maupun kelompok.

d. Bantuan Luaar Negeri baik berupa materi maupun tenaga ahli yang tidak mengikuti kaidah yang berlaku, apalagi sering terjadi manipulasi bantuan keagamaan dari luar negeri.

e. Kegiatan Aliran Sempalan, yang dilakukan baik perorangan maupun kelompokyang didasarkan atas sebuah keyakinan agama tertentu namun menyimpang jauh dari ajaran agama pokoknya.

3. Faktor Lokalitas dan Etnisitas

Faktor ini disebabkan migrasi penduduk dari desa ke kota maupun antar pulau. Selanjutnya masalah etnisitas, Indonesia memiliki potensi disintegratif yang tinggi. Sebagai contoh, penduduk asli atau putra daerah dan pendatang yang dengan mudah dapat menyulut perbedaan-perbedaan yang tak jarang berujung pada konflik, bahkan kerusuhan sosial.

Paradigma Pendidikan Multikultural di Perguruan Tinggi Perguruan tinggi sebagai sebuah lembaga tertinggi dalam strata pendidikan di Indonesia menjadi salah satu contoh wadah multikultural, terutama bagi perguruan tinggi yang berada di tengahtengah masyarakat yang multikultur. Tentu saja ini adalah sebuah tantangan dan pekerjaan rumah bagi perguruan tinggi Islam tersebut untuk membangun paradigma di tengah mayoritas umat islam yang menganggap adanya dikotomi keilmuan yang masih menghambat epistemologi penyatuan ilmu umum dan agama. 
Paradigma multikultur di perguruan tinggi hendaknya memiliki implementasi nilainilai multikultur sebagai berikut:

1. Mengembangkan wawasan multikultural kelembagaan di Perguruan Tinggi tersebut. Hal ini dapat dimulai, contohnya dengan: pembentukan berbagai pusat kajian di tingkat universitas dan fakultas, bahkan membentuk kajian islam bagi non muslim.

2. Aktif mengadakan kerjasama dengan berbagai lembaga baik dari dalam maupun dari luar, dan dengan universitas lintas agama.

3. Dari sisi akademik, setiap kurikulum dan silabi mata kuliah sebaiknya dibuat dalam interkoneksitas dan integritas dengan ilmu-ilmu lain yang memuat nilai-nilai kemanusiaan. Maka setiap kurikulum dan silabi mestilah memuat nilai-nilai multikultural.

Paradigma Pendidikan Multikultur Di Sekolah Sekolah atau Madrasah merupakan tempat yang sangat berpotensi sebagai penentu apakah generasi-generasi muda kedepannya nanti memiliki rasa toleran kepada keberagaman yang sangat multi tersebut atau tidak. Oleh karenanya pendidikan atau ajaran multikultur sangat urgen sekali.

Komponen yang sangat berpengaruh sekali adalah yang pertama, Guru. Guru/dosen memegang peranan penting dalam mengimplementasikan nilai-nilai keberagaman di sekolah. Apabila guru mempunyai paradigma pemahaman keberagaman yang inkluisf, maka dia juga akan mampu mengajarkan dan mengimplementasikan nilai-nilai keberagaman tersebut pada siswa di sekolah. Seorang guru/dosen harusnya bersikap demokratis, baik dalam sikap maupun perkataanya tidak diskriminatif.

Kedua, guru seharusnya mempunyai kepedulian yang tinggi terhadap kejadian-kejadian tertentu yang ada hubungannya dengan agama. Misalnya, ketika bom Bali (2003), maka bagi seorang guru yang berwawasan multikultural harus mampu menjelaskan keprihatinannya terhadap peristiwa tersebut.

Ketiga, guru sebaiknya menjelaskan bahwa inti dari ajaran agama adalah menciptakan kedamaian dan kesejahteraan bagi seluruh umat manusia, maka pemboman, invasi militer, dan segala bentuk kekerasan adalah sesuatu yang dilarang oleh agama.

Komponen kedua adalah Sekolah/Madrasah juga memegang peranan penting dalam membangun lingkungan pendidikan yang pluralis dan toleran. Langkah-langkah yang dapat ditempuh antara lain ; pengembangan materi Pendidikan Agama Islam Berbasis Multikultural. Hal ini bisa dimulai dengan pengembangan kurikulum materi pendidikan Agama Islam dengan nuansa multikultual, di antaranya adalah:

Pertama, materi Al Qur'an, tidak hanya mengajarkan ayat-ayat keimanan saja tetapi juga ditambah dengan ayat-ayat yang dapat memberikan pemahaman dan penanaman sikap ketika berinteraksi dengan orang yang berlainan agama, dengan tujuan peserta didik sedini mungkin sudah tertanam sikap tasamuh. Pengembangan materi tersebut diantaranya adalah: a). Materi yang berhubungan dengan pengakuan Al Qur'an akan adanyapluralitas dan berlomba dalam kebaikan (Al baqarah/2: 148); b) Materi yang berhubungan dengan pengakuan koeksistensi damai dalam hubungan antar umat beragam (Al Mumtahanah/60:8-9); c) materi yang berhubungan dengan keadilan dan persamaan (An Nisa'/4 : 35).

Kedua, materi fiqih, dapat diperluas dengan kajian fiqih siyasah (pemerintahan). Dalam fiqih siyasah terkandung konsepkonsep kebangsaan yang telah dicontohkan pada zaman Nabi, sahabat ataupun khalifah-khalifah sesudahnya. Sebagai contoh, Nabi Muhammad SAW mengelola dan memimpin masyarakat Madinah yang multi-etnis, multi-kultur, dan multi- 
agama. Keadaan masyarakat Madinah pada masa itu tidak jauh berbeda dengan keadaan masyarakat Indonesia. Ketiga, materi Akhlaq yang hanya memfokuskan kajiannya pada perilaku baik-buruk terhadap Allah, Rasul, sesama manusia, diri sendiri, serta lingkungan, penting artinya bagi penanaman dasar-dasar kebangsaan. Sebab, keabadian sebuah bangsa tergantung pada Akhlaq, apabila suatu bangsa meremehkan akhlaq, punahlah bangsa itu.

Sebagai contoh yang dilematis, dalam Al Qur'an, kehancuran kaum Luth disebabkan pilar-pilar moral. Agar pendidikan Agama bernuansa multikultural dapat mencapai objektifnya, peran guru PAI memang sangat berpengaruh sekali.

Keempat, materi SKI, materi yang mengajarkan tentang fakta dan realitas historis dimana didalamnya terdapat praktek-praktek interaksi sosial yang diaplikasikan Nabi Muhammad ketika membangun masyarakat Madinah. Dari segi historis proses pembangunan Madinah ditemukan fakta tentang pengakuan dan penghargaan atas niali pluralisme dan toleransi. Hal ini dapat ditanamkan pada peserta didik bahwa pembangunan masyarakat Madinah tidak lepas dari produk sejarah umat Islam yang juga diakui oleh orang barat yakni 'Madinah Charter'. Dalam piagam tersebut Nabi berhasil memberlakukan nilai-nilai keadilan, prisip kesetaraan, penegakan hukum, jaminan kesejahteraan bagi semua warga serta perlindungan terhadap kelompok minoritas. 


\section{KESIMPULAN}

Islam dan multiluturalisme akan menampakkan kehebatannya jika keduanya bisa berjalan dengan tawazun. Namun, itu bukan hal mudah seperti memutar arah jarum jam. Untuk memahami paradigma dan implementasi multikultural, perlu diterapkan prinsip-prisip atau nilai-nilai dasar diantaranya adalah: 1) Al-Ukhuwah, Persaudaraan, 2) AlHurriyah, Kebebasan, 3) Al-Musawah, Kesetaraan, dan 4) Al-Adalah, Keadilan.

Tidak bisa dipungkiri bahwa budaya banyak mempengaruhi pemahaman dan pengalaman ajaran islam. Oleh karena itu penting sekali menumbuhkan semangat saling pengertian di antara umat agar terbina silaturahim walaupun dalam keberagaman.

\section{Daftar Pustaka}

Http://ikassurabaya.blogspot.com/2007/07/mengkajiulangislammultikultural.html . Choirul Mahfud. 2013

Http:/aqidahfilsafatuinsuka.blogspot.com/2011/02/islamdanmultikulturalisme. html. By Irawan.25 Oktober 2013

Husaini, Adian. 2010. "Membentuk Manusia Berkarakter dan Beradab".Makalah 